\title{
A rollercoaster ride
}

\author{
Tom Jacobs
}

If only we knew then, what we know now. Biotech investing has changed over the past ten years in two major ways. First, thanks to fitful bursts of initial public offerings (IPOs), the growth and sheer diversity of companies listed on exchanges has greatly expanded the choices available to investors. And second, the burgeoning number of biopharmaceutical approvals has meant that a few biotech firms have increased in valuation, joining the ranks of the top drug makers and offering investors profitable, sustainable ventures for the first time.

\section{Waves, bubbles and tsunamis}

There are about 375 publicly traded biotech and drug companies today-down from roughly 425 two years ago, but many times more than ten years ago. This growth occurred in three broad IPO waves, beginning before and after the 1993 marketing of Eli Lilly's (Indianapolis, IN, USA) Humulin (recombinant insulin). Then came blockbusters, such as erythropoietin, boosting Amgen (Thousand Oaks, CA, USA; Nasdaq:AMGN). The monoclonal antibody drugs wave, still in progress, arrived next. Here, Genentech (S. San Francisco, CA, USA; NYSE:DNA) unerringly developed and chose the right partners for approvable drugs. Investors surfed to wealth.

But choice is not always a virtue. By mid1999, the Human Genome Program and competing efforts at Celera Genomics (Rockville, MD, USA; NYSE:CRA) seduced investors. Just as any 'dot.com/e-commerce' venture could seemingly raise millions on the market and watch its stock vault, so too could genomics. Gene sequencing and genomic data would 'revolutionize' drug making, making phar-

Tom Jacobs is cofounder of Complete Growth Investor, http://www.completegrowth.com, a stock service for individual investors. Tom owned no shares of these companies at time of writing. He welcomes your comments at tom@completegrowth.com. macogenomics and individualized medicine 'a reality.'

Investors flocked to data providers, such as Celera, research toolmakers, such as Affymetrix (Santa Clara, CA, USA; Nasdaq: AFFX), and drug makers like Millennium Pharmaceuticals (Cambridge, MA, USA; Nasdaq:MLNM) and Human Genome Sciences (Rockville, MD, USA; Nasdaq:HGSI). These and many dozens more companies had very different businesses, but riches lay in joining the chorus of genomics. Marketing departments knew the right words and even rebranded; Incyte Pharmaceuticals (today just Incyte, Wilmington, DE, USA; Nasdaq:INCY) became Incyte Genomics, for example. Cash flowed in as institutional investors bought the stories and new shares.

Then, a tsunami of investor reality suddenly engulfed the sector, causing unprecedented devastation. Although a few companies survived to make money today, most are impoverished survivors-living dead, picking among the last vestiges of cash raised during the boom's stock price inflation. Others didn't make it. Deltagen (San Carlos, CA, USA), Gliatech (Cleveland, $\mathrm{OH}, \mathrm{USA}$ ), Large Scale Biology (Vacaville, CA, USA), Cambridge Biotech and others filed for Chapter 11 bankruptcy protection. Some, like Hyseq (Sunnyvale, CA, USA) - the largest biotech IPO of 1997—squeaked by, collapsing from over a split-adjusted $\$ 300$ a share to a few paltry dollars in 2003, only to merge and rise from the wreckage as Nuvelo (Sunnyvale, CA, USA; Nasdaq:NUVO), recently raking in $\$ 100$ million from a new share offering. That's better than most investors, who bought anywhere except the bottom and didn't sell until too late.

\section{Biotech beats pharma}

Only a handful of biotechs achieved independent, self-funding success. These include Amgen, Genentech, Genzyme (Cambridge, MA, USA; Nasdaq:GENZ), MedImmune (Gaithersburg, MD, USA; Nasdaq:MEDI), Biogen-Idec (Cambridge, MA, USA; Nasdaq:
BIIB), and Serono (Geneva, Switzerland; NYSE:SRA). Today, Genentech and Amgen are the sixth and seventh largest drug companies in the world by enterprise value (see Supplementary Table 1). Five years ago Genentech wasn't even in the top 13 and Amgen was eleventh.

In fact, the two biotechs easily outpaced the large pharmaceutical companies, even including their dividends. Only four companies have fatter enterprise values today than in 2001 and Amgen and Genentech on a percentage basis lead the pack. Though all these companies benefited from biotech through acquisitions and/or partnerships, the pure biotechs are now powerful competitors for all their future biotech deals.

There might be more on this list were it not for the acquisitions of Immunex (Seattle, WA, USA), Sanofi-Synthelabo (Paris), and Centocor (Malvern, PA, USA), and Serono is now for sale as well. To stay independent and reward shareholders is truly a rare feat. In ten years, I'd expect to see Genzyme, BiogenIdec and MedImmune higher on the list, with a nod to dark horses Vertex Pharmaceuticals (Cambridge, MA, USA; Nasdaq:VRTX) and Elán Pharmaceuticals (Dublin, Ireland; NYSE: ELN).

\section{And now?}

The two main risks for biotech investors today are likely to continue for many years: valuation and speculation. The few profitable cash-generating companies all sell for multiples reflecting impossibly high growth expectations, offering investors great risk of sub-par returns. Only Amgen may prove an exception if its stock price continues to stagnate while earnings rise.

Little lies between the overpriced successes and the product-less speculations on one big drug's approval, so if you speculate, make small selective bets only with money you can afford to lose. If your stock doubles, sell half and leave the rest as long as you are comfortable. You would have slept better doing so in the past ten years, and ditto for the next ten. 